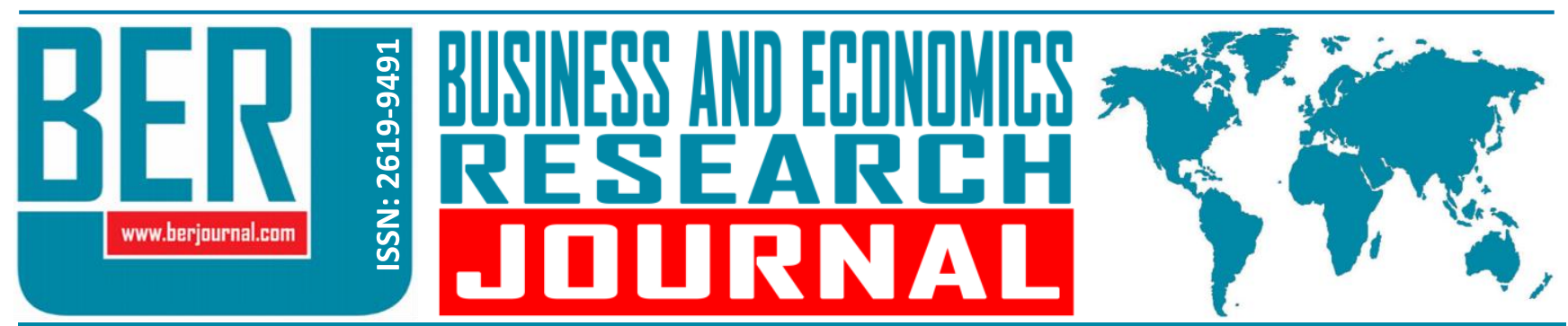

Business and Economics Research Journal Vol. 9, No. 3, 2018, pp. 651-663 doi: 10.20409/berj.2018.129

\title{
Does The Perception of Job Insecurity Bring Emotional Exhaustion? The Relationship between Job Insecurity, Affective Commitment and Emotional Exhaustion
}

\begin{abstract}
Gokhan Kerse $^{\mathrm{a}}$, Daimi Kocak ${ }^{\mathrm{b}}$, Sefik Ozdemir
Abstract: This studyexamines the effect of job insecurity on the level of emotional exhaustion and the role of affective commitment level on this influence. The survey (was conducted on 136 employees of a company operating in the manufacturing sector. Data were collected by questionnaire technique. In the process of analyzing the data was used SPSS and AMOS packaging programs.Structural equation modeling analysis was used to test the hypotheses developed in the research. The findings of the analysis showed that job insecurity effects affective commitment in the negative direction and emotional exhaustion in the positive direction. In addition, it has been determined that affective commitment plays a partial mediating role on the effect of job insecurity on emotional exhaustion. In other words; job insecurity affectsemotional exhaustion both directly and through affective commitment. The findings in the research are thought to contribute to both the literature and the business managers.
\end{abstract}

\begin{abstract}
Keywords: Job Insecurity, Affective Commitment, Emotional Exhaustion
\end{abstract}

JEL: D23, M10

$\begin{array}{ll}\text { Received } & : 12 \text { March } 2018 \\ \text { Revised } & : 12 \text { April } 2018 \\ \text { Accepted } & : 15 \text { May } 2018 \\ \text { Type } & : \text { Research }\end{array}$

\section{Introduction}

Recent global competition, rapid technological changes and increasing customer expectations have affected the way businesses carry out their operations. These new methods have some positive effects on the employees as well as some negative effects (Alarco et al., 2012). As a result of increasing economic competition some of the crisis-hit businesses have gone to shrink to survive. Business managers thought that shrinking is a good solution to increase their efficiency and reduce labor costs; in order to deal with the situation during the crisis, they first used the method of firing workers (Bosman, 2005). The dismissal of employees causes the phenomenon job insecurity, which is expressed as to perceive threats to experience job loss and not have the power to overcome these threats while there is the desire or expectation to stay long in the employee's current job (Elst et al., 2014).

Job insecurity is a negative situation that triggers unwanted outputs in employees. The researches reveal that job insecurity has led to a decrease in job satisfaction (Reisel et al., 2007), and organizational commitment (Peene, 2009), an increase in stress levels (Gaunt \& Benjamin, 2007: 349) causes a decrease in the performance (Wang et al., 2014). It is stated that the most important source that organizations have today is qualified employees as they are the most important resource that will enable organizations to adapt to the

Cite this article as: Kerse, G., Kocak, D., \& Ozdemir, S. (2018). Does the perception of job insecurity bring emotional exhaustion? The relationship between job insecurity, affective commitment and emotional exhaustion. Business and Economics Research Journal, 9(3), 651-663.

The current issue and archive of this Journal is available at: www.berjournal.com

Asst. Prof., PhD., Karamanoglu Mehmetbey University, Faculty of Economics and Administrative Sciences, Karaman, Turkiye, gokhankerse@hotmail.com (ORCID ID: 0000-0002-1565-9110)

b Asst. Prof., PhD., Erzincan University, Ali Cavit Celebioglu Civil Aviation School, Erzincan, Turkiye dkocak@erzincan.edu.tr (ORCID ID:Y0000-0001-9099-2055)

Asst. Prof., PhD., Aksaray University, Faculty of Health Sciences, Aksaray, sefikozdemir@aksaray.edu.tr (ORCID ID: 0000-00033005-0570) 
ever-renewing business environment and solve the problems they face. Despite this, organizations might take out some of the employees they think are less qualified in times of crisis. However, this does not prevent the others' fear of losing their job. Employees who continue to work in such situations may be less likely to exhibit mildly beneficial behaviors. From this point of view, our study examines whether job insecurity affects the emotional exhaustion of employees and whether their affective commitment towards their companyhas a mediating role in this effect.

\section{Job Insecurity}

People, more or less, fear losing their jobs no matter which sector they belong to or what work they perform. In recent years, both changes and crises in working life and the increase in the firing of employees due to applications such as downsizing and flexible working hours has caused job insecurity to become a major issue for employees. In the 1950s, employees' job insecurity was a topic discussed indirectly in issues related to their being motivated. Herzberg (1959) and Maslow (1954) who did important research on motivation, suggested that the job security motivated employees and it was an essential prerequisite for the welfare of the workforce (Richter, 2011). Since the 1980s, job security has become the center of debates about change in work quality. Greenhalgh and Rosenblatt (1984) described job insecurity as the weakness that the individual perceives while continuing to the work under threat. This concept has begun to be considered as a source of stress due to results of Greenhalgh and Rosenblatt's research related to job insecurity (Martínez et al., 2010).

Job insecurity can be described as the difference between the job security an individual expects and the job security he has and the existence of the uncertainty about whether or not the individual can continue to work (Dereli, 2012). Job insecurity includes not only the threat of perceived job loss, but also the loss of valuable job characteristics such as wages, status, promotion and access to resources. Job insecurity lies between employment and unemployment, because job insecurity refers to the people employed under the threat of unemployment. Job insecurity has a number of components. These components are as follows (Dachapalli \& Parumasur, 2012):

- Severity of threat related to business continuity or business characteristics,

- The importance of the characteristics of the work for the individual,

- The threat that the employee perceives about the variables that he expects to have a negative impact on his work,

- The total importance of the above changes for the individual,

- The situation that the individual does not have the necessary strength and / or competence to control the above factors.

These components may differ for those in an organization. For example, the strength and competencies an employee has to keep these factors under control can be different from those with the same status and workload. Likewise, while the characteristics of one's job are extremely important to one individual, they might have very little prescription for another one (Dede, 2017).

The researches on job insecurity have found that workers who are at risk of losing their work experience higher levels of negative emotions such as stress, anxiety and depression compared to employees who are not at risk of losing their jobs (Nella et al., 2015; Burgard et al., 2008; Smit et al., 2016). In addition, it has been found that those who feel job insecurity are less loyal to their company than those who do not feel insecurity (Furaker \& Berglund, 2013, Ünsal-Akbıyık et al., 2012; Piccoli et al., 2011; Peene, 2009) and have higher level of exhaustion (Bosman et al., 2005; Tilakdharee et al., 2010, Çetin \& Turan, 2013).

\section{Affective Commitment}


Drucker (1998) states that the most critical and important source in a constantly developing business environment is qualified human resources. Due to the difficulty of finding and recruiting qualified workers that are the most important source for organizations enabling effective competition by using new information, their commitment to their organizations remains an important research topic (Lam \& Liu, 2014). The concept of loyalty is often used to refer to any valuable items related to the costs of items such as time, labor, money lost when employees leave the organization (Meyer \& Allen, 1984). From this perspective; employees who work in situations where an organization guarantees more socio-economic benefits might be said to show behaviors that protect the organization, make efforts to increase the reputation of the organization, and serve the interests of the organization rather than its own interests (Graham, 1991).

It is suggested in the literature that employees who are effectively connected to their organizations are willing to participate voluntarily in the activities of the organization, remain in the organization and realize the aims of the organizations and feel a sense of belonging (Rhoades, Eisenberger \& Armeli, 2001). In other words, while employees with high organizational commitment exhibit behaviors towards staying as a member of an organization, employees with low organizational commitment exhibit withdrawal behaviors by entering into retreat behavior (Colquitt, Lepine $\&$ Wesson 2015). For this reason, commitment is important for the continuity of organizational life.

Commitment is a social act and refers to the attachment of one person to certain values related to organizational goals (Miroshnik, 2013). Meyer and Allen (1991) defined organizational commitment as a psychological relationship between workers and their organization in general terms. Although there are many different definitions in the literature, Mowday, Steers and Porter (1979) stated that the concept of commitment can be characterized by at least three elements. These elements are:

- Acceptance of and a strong belief in the goals and values of the organization,

- Willingness to make efforts on behalf of the organization and

- Strong desire to become a knit member

Organizational commitment was initially examined as a one-dimensional concept. However, different dimensions developed by different researchers in later periods have enriched the concept in terms of content and meaning (Uslu, 2014). Although there are different classifications related to the dimensions of organizational commitment, according to Meyer and Allen (1991) organizational commitment consists of normative commitment, emotional commitment and continuity commitment components (Taşkaya \& Şahin, 2011).

Meyer and Allen (1997), who observed that affective commitment was related to productive behaviors and it made a meaningful contribution to the organization, indicated that the most useful component of organizational commitment is affective commitment (Frow, 2007). Meyer and Allen (1991) defined emotional commitment as employees' identification with the organization, voluntary participation in organizational activities, and emotional engagement with the organization. In another definition, affective commitment is defined as "employees' held in organizational objects more tightly, identification and integration with the organization, acceptance of organizational goals and values, and extraordinary efforts to benefit the organization" (Gürbüz, 2006: 59-60). Research on the subject suggests that as affective commitment to the organization develops, employees may remain committed to their managers and working groups or teams (Vandenberghe, Bentein \& Stinglhamber, 2004).

\section{Emotional Exhaustion}

The concept of burnout was first described by Freudenberger (1974) and Maslach (1976). Freudenberger explains the burnout as one's reduced energy, weariness and exhaustion as a result of the intense work and that it is more likely to occur in people who work in intensive interaction with other people (Freudenberger, 1974). Maslach classifies burnout as emotional exhaustion of one's while working and depersonalization to other people, and decrease in personal success as a result. Maslach noted that the most important of these three dimensions (emotional exhaustion, depersonalization and reduced personal 
accomplishment) is the emotional exhaustion because people often emphasize emotional exhaustion when they talk about themselves or others' burnout. Emotional exhaustion is the key point of the concept of burnout and is the dimension that best describes the concept (Maslach \& Jackson, 1981; Maslach et al., 2001). Emotional exhaustion is the first stage of the exhaustion according to the classification made by Maslach. In other words, the emotional exhaustion of the person comes out before the other two dimensions of burnout that are the depersonalization of the person to other individuals (colleagues, customers) and the decline in personal success. For this reason, emotional exhaustion is more important than other burnout dimensions (Maslach \& Jackson, 1981; Maslach et al., 2001; Şıklar \& Tunalı, 2012;Yürür \& Ünlü, 2011). Emotional exhaustion refers to the stress dimension of the exhaustion and is defined as the decrease in the emotional and physical resources of the individual (Maslach et al., 2001).

\section{Research Hypothesis}

The perception of job insecurity is a negative situation that brings together many individual and organizational consequences. In this research, only affective commitment and emotional exhaustion among the aforementioned results were discussed. Perception of the possibility of losing an employee's job will reduce the level of affective commitment to the organization. As a matter of fact, the research findings in the literature support this expectation. For example, Ünsal-Akbıyık et al. (2012) found that job insecurity in the tourism sector has a negative and significant effect on affective commitment. Peene (2009) found that increased perceptions of job insecurity of the staff who worked at a private cargo company had a negative and meaningful effect on the affective commitment to the agency. Piccoli et al. (2011) found in their research that job insecurity had a negative and significant influence on the affective commitment of blue-collar employees to the organization in a company that functions in service sector.

The following hypothesis has been developed according to the results of the literature dealing with the relationship between job insecurity and affective commitment.

$\boldsymbol{H}_{1}$ : The perception of job insecurity affects the employee's affective commitment level negatively and significantly.

Another consequence of perceiving that the employee can be fired from temporary or permanent work is the increase in the level of emotional exhaustion. As a matter of fact, research findings in the literature also support this situation. For example, Tilakdharee et al. (2010) found a positive and significant effect of job insecurity on emotional exhaustion in their research on a firm operating in the education sector. Bosman et al. (2005) found that job insecurity was positively and significantly related to burnout in the research they conducted with employees of a company's human resources department operating in the finance sector. Ismail (2015) found that the increase in perceptions of job insecurity among employees had a positive and significant effect on burnout perceptions. As a result of questionnaire studies with teachers in education sector, Çetin and Turan (2013) found that job insecurity positively and significantly affected emotional exhaustion.

According to the research results above, which deal with the relationship between job insecurity and emotional exhaustion, the following hypothesis has been established. significantly.

$\boldsymbol{H}_{2}$ :The perception of job insecurity affects employee's emotional exhaustion level positively and

It is expected that the level of emotional exhaustion will decrease as employees are more integrated with the organization and are pleased to be members of the it. Researches in the literature have also provided findings in parallel with this expectation. For example, Yener et al. (2014) found in the research they conducted with employees in a logistics sector that organizational commitment affected burnout negatively and significantly. Tosun and Ulusoy (2017) and Akpınar et al. (2013) found as a result of a survey conducted by employees in the health sector that affective commitment negatively and significantly affects emotional exhaustion. On the research on bank employees, Aslam et al. (2012) found that affective commitment had a negative and significant effect on emotional exhaustion. 
In the light of the research results above investigating the relationship between affective commitment and emotional exhaustion, the following hypothesis has been developed.

$\boldsymbol{H}_{3}$ : Affective commitment affects employee's emotional exhaustion level negatively and significantly.

When the above-mentioned research findings are examined, affective commitment decreases (Ünsal-Akbıyık et al., 2012; Peene, 2009; Piccoli et al., 2011) and emotional exhaustion increases (Tilakdharee et al., 2010; Bosman et al., 2005; İsmail, 2015) with the perception of job insecurity. On the other hand, research in the literature shows that affective commitment affects the emotional exhaustion negatively (Yener et al., 2014; Tosun \& Ulusoy, 2017; Akpınar et al., 2013). This leads to the expectation that affective commitment may play a mediating role in the effect of job insecurity on emotional exhaustion. In other words, the affective commitment of the employee who perceives job insecurity will decrease and the employee whose affective commitment decreases will experience more emotional exhaustion.

In the light of these expectations and explanations, the following hypothesis has been developed regarding the intermediary effect.

$\boldsymbol{H}_{4}$ : Affective commitment plays a mediating role in the effect of job insecurity on employees' emotional exhaustion level.

In the light of the hypotheses developed above, the following research model has been developed:

Figure 1. Research Model

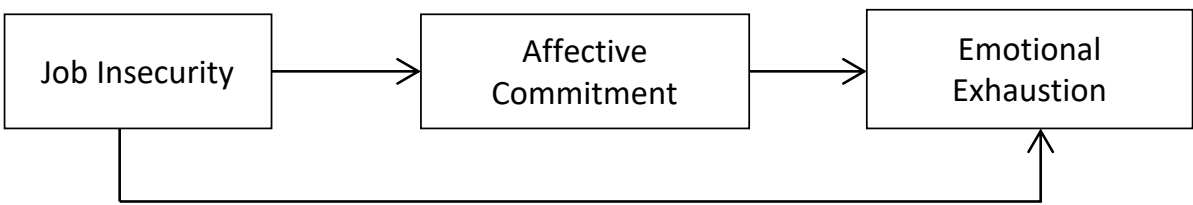

\section{Method}

\subsection{Aim and Sample}

The aim of this research is to determine if the job insecurity has an effect on emotional exhaustion and whether affective commitment has a mediating role on the influence. To this end, a business operating in the pipe manufacturing sector within a province in Turkey and transferred to the Savings Deposits Insurance Fund (SDIF) has been chosen as the universe. All employees in this operation with 160 employees were included in the study and questionnaires were distributed to the employees. Of the distributed surveys, 140 were returned, and 136 surveys were considered appropriate because of data loss in some surveys. SPSS and AMOS programs were used in the analysis of the data. The reason why the research is conducted in this business dealing with pipe manufacturing is to determine the perceived job insecurity of these employees who are managed by the trustee and to determine the effect of this perceive on their affective commitment and emotional exhaustion levels.Demographic findings of 136 employees working in the manufacturing sector and participating in the research are presented in Table-1 below:

When the findings in Table 1 are examined, it is seen that most of the participant employees are composed of male $(85.3 \%)$ and married (70.6\%) individuals. In terms of age variable, the ratio of employees below 25 years $(8.8 \%)$ is the lowest and the proportion of employees between the ages of $26-35(58.8 \%)$ is the highest. In terms of education, it is seen that the employees having a high school or lower education degree have the highest ratio (70.6\%). As for the duration of work, it is seen that the number of individuals working for $1-5$ years is higher $(59.6 \%)$.

Table 1. Demographics of the Participants 


\begin{tabular}{llcl}
\hline VARIABLE & CATEGORY & FREQUENCY & (\%) \\
\hline Gender & Male & 116 & 85,3 \\
Marital Status & Female & 20 & 14,7 \\
& Married & 96 & 70,6 \\
\hline Age & Single & 40 & 29,4 \\
& Below 25 & 12 & 8,8 \\
& $26-35$ & 80 & 58,8 \\
\hline \multirow{2}{*}{ Educational Status } & Over 35 & 44 & 32,4 \\
& High school or below & 96 & 70,6 \\
& Associate Degree & 20 & 14,7 \\
Working for (years) & Undergraduate & 20 & 14,7 \\
& Less than 1 & 16 & 11,8 \\
& $1-5$ & 81 & 59,6 \\
\hline
\end{tabular}

\subsection{Data Collection Instruments}

While the questionnaire was being prepared in the research, the measurement tools whose reliability and validity were tested in previous studies were used. In order to measure employees' job insecurity perceptions, a 6-item scale of Zoghbi-Manrique-de-Lara et al. (see Annex 1); to measure affective commitment levels, a 6-item scale developed by Allen and Meyer (1990) and to measure emotional exhaustion levels 9-item scale developed by Maslach and Jackson (1981) were used. The items on each scale are 5 -likert type $(1=$ strongly disagree 5 = strongly agree $)$.

\section{Findings}

\subsection{Factor Analysis of the Instruments}

The construct validity of each scale used in the research was determined by confirmatory factor analysis (CFA). In confirmatory factor analysis, job insecurity scale items were coded as "Jl"; emotional attachment scale items as "AC" and emotional exhaustion scale items as "EE". The reference point in the analysis was to have a higher value than 0.40 for the standardized regression coefficients. On the other hand, if the reference values in the scale adaptation indices were not provided, modifications were made between the items in order to improve the index values. In the analyzes, index values taken as reference are as follows (Kerse, Babadağ \& Kerse, 2017): CMIN / DF $=0<\chi 2$ / sd $\leq 5 ; \mathrm{CFI}=\geq, 90 ; \mathrm{IFI}=\geq, 90 ; \mathrm{TLI}=\geq 90$; and RMSEA $=<$, $05-, 08 \leq$. Both the confirmatory factor analysis and the structural equation modeling adaptation index values provided the necessary criteria in the analyzescarried out. In the research, the reliability of the scale was determined by examining the internal consistency of the scales, and the scales were found to be in a reliable level (cronbach alpha: job insecurity 0,804 , affective commitment 0,777 ; emotional exhaustion 0,896 ).

In confirmatory factor analysis of 6 items on the job insecurity, one item (JI5: I might be forced to accept an agreement on early retirement) has been excluded from the analysis because its factor load was below 0.40 . On the other hand, since some adaptation index values in the analysis did not meet the reference values, modifications were made between the items (between J/1-J/2 and Jl3-Jl6). Confirmatory factor analysis findings for the job insecurity scale are shown in Figure-2:

Figure 2. CFA on Job Insecurity Scale 


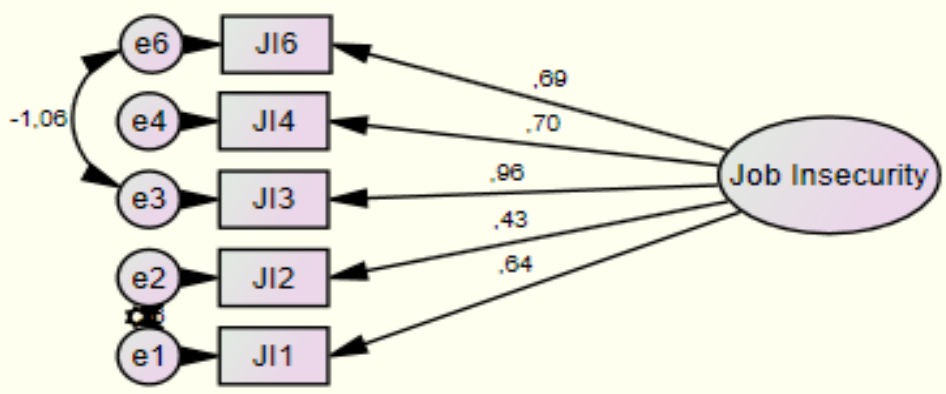

Table 2 shows the values of fit goodness obtained after the modification of the job insecurity scale. The values in the table indicate that the necessary criteria are met.

Table 2. Post-Modification Index Values

\begin{tabular}{llllll}
\hline Indexes & $\begin{array}{c}\text { Reference } \\
\text { Value }\end{array}$ & $\begin{array}{c}\text { Job } \\
\text { Insecurity }\end{array}$ & $\begin{array}{c}\text { Emotional } \\
\text { Exhaustion }\end{array}$ & $\begin{array}{c}\text { Affective } \\
\text { Commitment }\end{array}$ & $\begin{array}{c}\text { Research } \\
\text { Model }\end{array}$ \\
\cline { 3 - 6 } & & & & & \\
\hline CMIN/DF & $0<\chi 2 / s d \leq 5$ & 1,064 & 1,452 &, 186 & 2,245 \\
\hline CFI & $\geq, 90$ &, 999 &, 986 & 1,000 &, 911 \\
\hline IFI & $\geq, 90$ &, 999 &, 986 & 1,000 &, 913 \\
\hline TLI & $\geq, 90$ &, 997 &, 975 & 1,000 &, 901 \\
\hline RMSEA & $<, 05-, 08 \leq$ &, 022 &, 058 &, 000 &, 076 \\
\hline
\end{tabular}

Confirmatory factor analysis was performed on 6 items of affective commitment scale in the research. AC2 (I feel the problems of this business as my own problem) and AC6 (This business has a big meaning for me in my life) coded items were excluded from the analysis because of their factor load being below 0.40 . Afterwards, the model was restarted. On the other hand, some model fit indexes did not meet the criteria, and therefore, modifications were made between AC1 and AC5.The post-modification values in Table 2 seem to provide the necessary criteria. Confirmatory factor analysis findings of the scale are presented in Figure 3:

Figure 3. CFA on Affective Commitment Scale

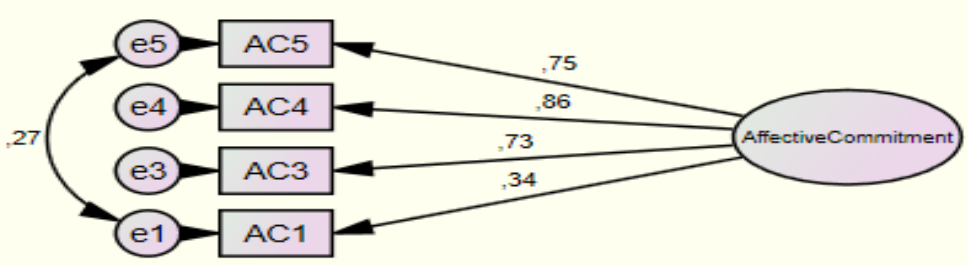

Confirmatory factor analysis was performed on 9-item emotional exhaustion scale and factor loadings of the items were found to provide the necessary criteria. On the other hand, modifications were made between the items in order to improve the scale adaptation index values (between EE1-EE2, EE2-EE3, EE3-EE9, EE4-EE7, EE6-EE7 and EE8-EE9). Post-modification values provide criteria (see,Table 2). Confirmatory factor analysis findings of the scale are presented in Figure 4:

Figure 4. CFA on Emotional Exhaustion Scale 


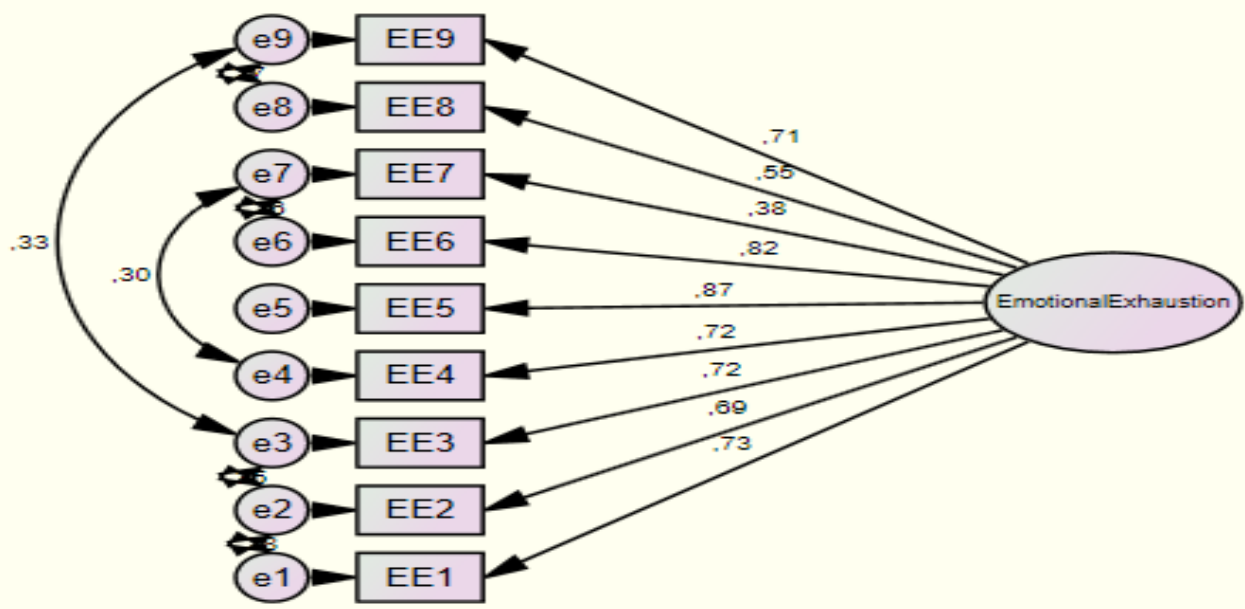

\subsection{Findings on Correlation Analysis and Hypothesis}

Before analyzing the structural equation modeling for the hypothesis testing in the research, the relationships between the variables were examined. Correlation analysis was made with this aim and the findings are presented in Table-3:

Table 3. Relation between the Variables

\begin{tabular}{lcclll}
\hline Variables & $\bar{x}$ & SS & $\mathbf{1}$ & $\mathbf{2}$ & $\mathbf{3}$ \\
\hline 1-Job Insecurity & 2,756 &, 943 & 1 & & \\
\hline 2-Emotional Exhaustion & 2,651 &, 944 &, $416^{* *}$ & 1 & \\
\hline 3- Affective Commitment & 3,609 &, 972 &,$- 480^{* *}$ &,$- 564^{* *}$ & 1 \\
\hline
\end{tabular}

When the findings in Table 3 are examined, it can be said that the manufacturing sector employees relatively perceive job insecurity (mean $=2,756$ ) and emotional exhaustion (mean $=2,651$ ), and partly feel affective commitment to their organizations (mean $=3,609$ ). When the relations between variables are examined; it is seen that there is a positive relation between employees' job insecurity perception and emotional exhaustion $(r=, 416 ; p=, 000)$; and negative relation between emotional attachment and emotional attachment $(r=-, 480 ; p=, 000)$. When the relationship between emotional exhaustion and affective commitment is examined; it is negative sided and significant $(r=-, 564 ; p=, 000)$.

Structural equation model analysis was used to test the hypotheses developed in the research. Before structural equation model analysis, it was examined whether there is a problem of multiple linearity between variables; it was found that there was no multiple linear connection problem because the variance inflation factor (VIF) were less than 10 and tolerance index (variance ratio unexplained variance) values were more than 0,10 . Hence, it has come to the conclusion that structural equation modeling analysis could be done. Maximum likelihood method was used in structural equation modeling analysis. In the research model, job insecurity was the exogenous variable; affective commitment and emotional exhaustion were considered as endogenous variables; the estimation results obtained in the analysis are shown in Figure 5:

Figure 5. Estimation Results of the Research Model 


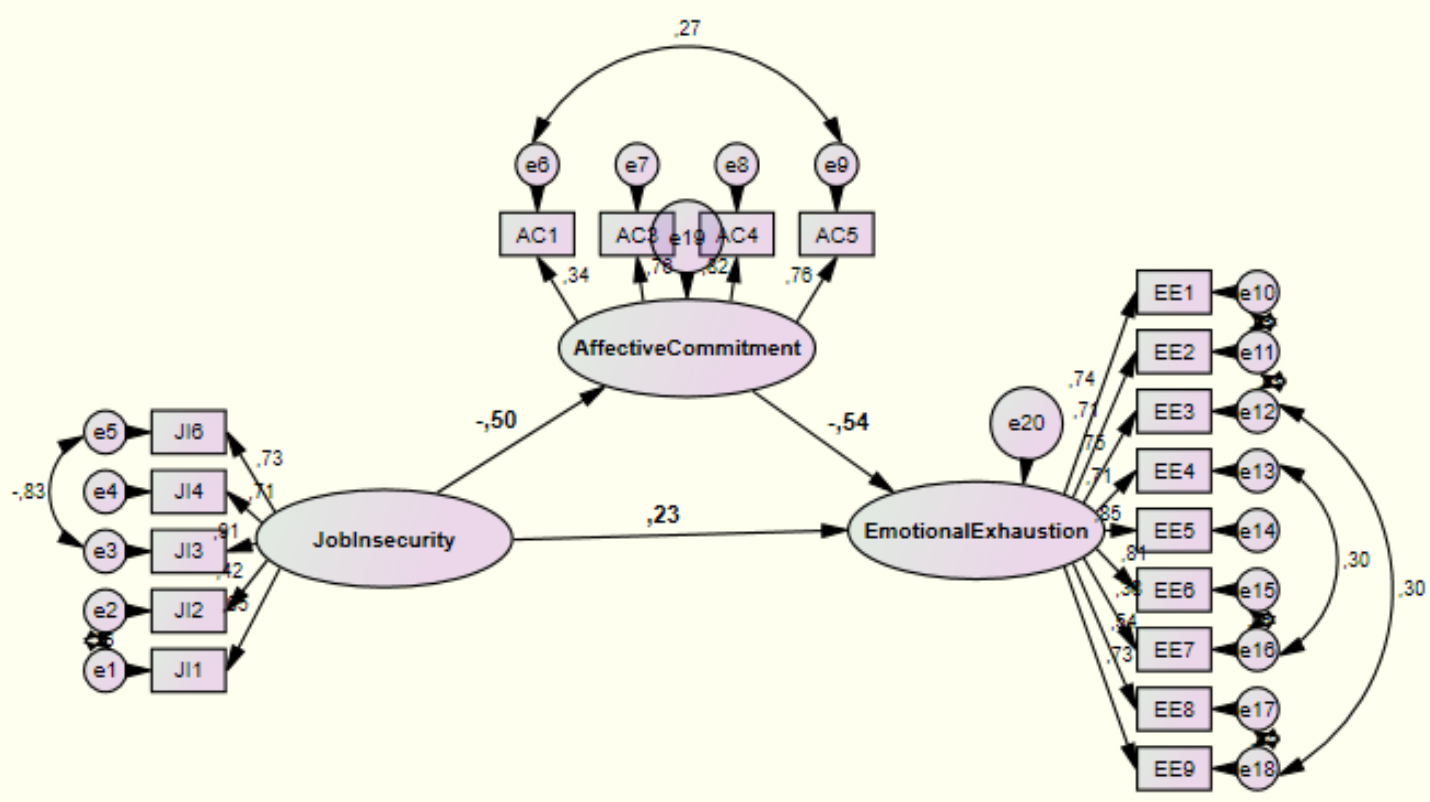

Estimates of the research model in structural equation modeling are presented in Table-4 below:

Table 4. Estimation Values of the Research Model

\begin{tabular}{|c|c|c|c|c|c|c|c|}
\hline Hypothesis & $\begin{array}{l}\text { Dependent } \\
\text { Variable }\end{array}$ & & $\begin{array}{l}\text { Independent } \\
\text { Variable }\end{array}$ & $\begin{array}{l}\text { Standardized } \\
\text { R. Y. }\end{array}$ & S.E. & C.R. & $\mathbf{p}$ \\
\hline $\mathrm{H}_{1}$ & $\begin{array}{l}\text { Affective } \\
\text { Commitment }\end{array}$ & $<---$ & Job Insecurity &,- 504 & ,081 & $-3,055$ & ,002 \\
\hline $\mathrm{H}_{2}$ & $\begin{array}{l}\text { Emotional } \\
\text { Exhaustion }\end{array}$ & $<<--$ & Job Insecurity & 227 & ,097 & 2,432 & 015 \\
\hline $\mathrm{H}_{3}$ & $\begin{array}{l}\text { Emotional } \\
\text { Exhaustion }\end{array}$ & $<---$ & $\begin{array}{l}\text { Affective } \\
\text { Commitment }\end{array}$ &,- 542 & 372 & $-3,073$ & ,002 \\
\hline
\end{tabular}

When the findings in Table- 4 above are examined, it is seen that job insecurity affects affective commitment negatively $(-, 504)$ and significantly $(, 002)$; and it affects emotional exhaustion positively $(, 227)$ and significantly $(, 015)$; thus supporting hypothesis $\mathrm{H}_{1}$ and $\mathrm{H}_{2}$. In other words; the increase in employees' perceptions of job insecurity diminishes their affective commitment and increases their emotional exhaustion levels.

Another finding presented in Table 4 is that affective commitment affects emotional exhaustion negatively $(-, 542)$ and significantly $(, 002)$, thus supporting the $\mathrm{H}_{3}$ coded hypothesis. In other words; the level of emotional exhaustion has decreased with the increase in the affective commitment of employees.

In order to determine whether affective commitment has anmediating role on the effect of job insecurity on the emotional exhaustion, Baron and Kenny's (1986) mediation criteria are taken as reference. According to these criteria, the independent variable should both affect the dependent variable and the mediating variable significantly. On the other hand, when the independent variable and the mediator variable are included together in the analysis, the effect of the independent variable is reduced (or no effect at all) and the mediator variable must have an effect on the dependent variable. In line with these criteria, the affective commitment mediating variable was removed from the model and the effect of job insecurity on emotional exhaustion was investigated. In this case, job insecurity affects emotional exhaustion positively $(, 486)$ and significantly $(, 000)$. As seen in the findings in Table 4, the effect of job insecurity on the emotional exhaustionwas reduced $(227)$ when affective commitment was included in the model as mediating variable 
and the effect went on significantly $(, 015)$. On the other hand, affective commitment significantly affected emotional exhaustion in the mediator model. This suggests that affective commitment plays a partial role on the effect ofjob insecurity on emotional exhaustion, so $\mathrm{H}_{4}$ is supported.

\section{Discussion and Results}

In this research on employees of an enterprise servicing in manufacturing sector that has been transferred to the Savings Deposits Insurance Fund (SDIF), the following findings were considered to contribute to the literature:

In the research, firstly, the employees of the sector partially perceived job insecurity and emotional exhaustion, and they were found to have partialaffective commitment. The reason for this may be the fact that employees are negatively evaluating the situation and seeing the future uncertain because the management of the said entity is transferred to the SDIF and the management is on the trustee. Employees may perceive this as ambiguity, although managers who have been appointed as trustees may struggle to maintain the life of the enterprise and continue employing them.

Another finding in the study is that job insecurity affects affective commitment negatively and emotional exhaustion positively. The sense of belonging mood was reduced by perceiving that employees could be removed from their jobs temporarily or permanently. This finding supports the findings of the studies in the literature (Ünsal-Akbıyık et al., 2012; Peene, 2009; Piccoli et al., 2011). Perceiving that employees can be removed from their jobs temporarily or permanently has also increased their perceptions of coldness, malaise and endurance against work. This finding supports the findings of some other researches by Tilakdharee et al. (2010), Bosman et al. (2005) and Ismail (2015).

According to the findings, affective commitment has a negative and significant effect on emotional exhaustion. This result is parallel to the research findings in the literature (Yener et al., 2014; Tosun \& Ulusoy, 2017; Akpınar et al., 2013). Employees are less likely to feel their emotional resources in their work run out when they integrate with the organization and feel satisfaction with being a member of the organization. On the contrary, with the disintegration of the employees into the organization and the loss of affective commitment, they feel that their emotional resources are exhausted in their work and they cannot concentrate on their jobs.

Findings related to mediating effect showed that the affective commitment has a partial mediating role of the job insecurity perception on the level of emotional exhaustion. This finding implies that the job insecurity perception affects emotional exhaustion both directly and indirectly through emotional commitment. In other words, perceiving that an employee will not be excluded from the work temporarily or permanently has allowed him to perceive that he is both integrated with his organization and strengthened his belonging, and that his emotional resource in his work is also run out less. Affective commitment besides job insecurity has also affected emotional exhaustion. The coldness towards the work and burnout level of the employee who has strengthened the belonging to the organization through affective commitment work decreased; the employee could work psychologically.

In the cultures where collectivist behavior is exhibited, such as Turkey (Güney \& Çetin, 2003), job security is very important. Indeed, while individualist cultures emphasize on autonomy and task variety, collectivist cultures emphasize more on job security and good working conditions. Therefore, employees with collectivist cultural values are more negatively affected by job insecurity (Probst \& Lawler, 2006). For this reason, in our country, the perception of job security is of great importance for achieving positive organizational outcomes.

In addition to the above-mentioned findings of the research, which are thought to contribute to the literature, there are some limitations in terms of time, location and employees included in the research. Firstly, cross-sectional and quantitative data were gathered in the research and employees answered the questions with instant psychology. Besides, the research was carried out in a business which is taken over by the SDIF and which is managed by a trustee. The fact that the research is not conducted on an enterprise 
that is not managed by a custodian in the same sector and the fact that it is not compared with such an enterprise is another important limitation of the research. Considering the limitations of the research, it is possible to propose researches to be done in the future to contribute by diversifying the research sample and improving the research model.

\section{References}

Alarco, B., De Cuyper, N., \& De Witte, H. (2012).The relationship between job insecurity and well-being among Peruvian workers. Romanian Journal of Applied Psychology, 14(2), 43-52.

Allen, N.J., \& Meyer, J.P. (1990).The measurement and antecedents of affective, continuance and normative commitment to the organization. Journal of Occupational Psychology, 63, 1-18.

Aslam, M. S., Ahmad, F., \& Anwar, S. (2012). Job burnout and organizational citizenship behaviors: Mediating role of affective commitment. Journal of Basic and Applied Scientific Research, 2(8), 8120-8129.

Baron, R.M., \& Kenny, D.A. (1986).The moderator-mediator variable distinction in social psychological research conceptual, strategic and statistical considerations. Journal of Personality and Social Psychology, 51(6), 11731182.

Burgard, S. A., Brand, J. E., \& House, J. S. (2009). Perceived job insecurity and worker health in the United States. Social Science \& Medicine, 69(5), 777-785.

Colquitt, J., Lepine, J. A., \& Wesson, M. (2015).Organizational behavior: Improving performance and commitment in the workplace, Fourth Edition. McGraw-Hill Irwin.

Dachapalli, L. A. P., \& Parumasur, S. B. (2012). Employee susceptibility to experiencing job insecurity. South African Journal of Economic and Management Sciences, 15(1), 16-30.

Dede, E. (2017). İ̧̧ güvencesizliği algısının ve örgütsel güven düzeyinin örgütsel vatandaşlık davranışı üzerindeki etkileri: Devlet ortaokulu ve özel ortaokul öğretmenleri üzerine bir araştırma. İstanbul Ticaret Üniversitesi Sosyal Bilimler Enstitüsü, Yayınlanmamış Doktora Tezi, İstanbul.

Dereli, B. (2012). İ̧ güvencesizliği kavramı ve banka çalışanlarının iş güvencesizliğine yönelik algılarının demografik özelliklerine göre incelenmesi. İstanbul Ticaret Üniversitesi Sosyal Bilimler Dergisi, 11(21), 237-256.

Freudenberger, H. J. (1974). Staff burn-out. Journal of Social Issues, 30(1), 159-165.

Frow, P. (2007). The Meaning of commitment in professional service relationships: A study of the meaning of commitment used by lawyers and their clients. Journal of Marketing Managment, 23(3), 243-265.

Furaker, B., \& Berglund, T. (2014). Job insecurity and organizational commitment. RIO: Revista Internacional de Organizaciones, 13, 163-186.

Gaunt, R., \& Benjamin, O. (2007). Job insecurity, stress and gender: The moderating role of gender ideology. Community, Work and Family, 10(3), 341-355.

Graham, J. W. (1991). An essay on organizational citizenship behavior. Employee Responsibilities and Rights Journal, 4(4), 249-270.

Greenhalgh, L., \& Rosenblatt, Z. (1984). Job insecurity: Toward conceptual clarity. Academy of Management Review, 9(3), 438-448.

Güney, S., \& Çetin, A. (2003). Kültürün girişimciliğe etkisi ve Türkiye'de girişimcilik kültürü. H.Ü. iktisadi ve Idari Bilimler Fakültesi Dergisi, 21(1), 189-210.

Gürbüz, S. (2006). Örgütsel vatandaşlık davranışı ile duygusal bağııık arasındaki ilişkilerin belirlenmesine yönelik bir araştırma. Ekonomik ve Sosyal Araştırmalar Dergisi, 3(1), 48-75.

Ismail, H. (2015). Job insecurity, burnout and intention to quit. International Journal of Academic Research in Business and Social Sciences, 5(4), 310-324.

Kerse, G., Babadağ, M., \& Kerse, Y. (2017). Girişimcilik eğitiminin girişimcilik niyetine etkisi: Girişimsel öz-yetkinliğin aracı rolü. Süleyman Demirel Üniversitesi Sosyal Bilimler Enstitüsü Dergisi, 29, 633-656.

Laba, K., Bosman, J., \& Buitendach, J. H. (2005). Job insecurity, burnout and organisational commitment among employees of a financial institution in Gauteng. SA Journal of Industrial Psychology, 31(4), 32-40.

Lam, L., \& Liu, Y. (2014). The identity-based explanation of affective commitment. Journal of Managerial Psychology, 29(3), 321-340. 
Martínez, G., De Cuyper, N., \& De Witte, H. (2010). Review of the job insecurity literature: The case of Latin America. AvancesenPsicologíaLatinoamericana, 28(2), 194-204.

Maslach, C., \& Jackson, S.E. (1981).The Measurement of Experienced Burnout. Journal of Occupational Behavior, 2, 99113.

Maslach, C., Schaufeli, W. B., \& Leiter, M. P. (2001).Job burnout. Annual review of psychology, 52(1), $397-422$.

Meyer, J. P., \& Allen, N. J. (1984).Testing the "side-bet theory" of organizational commitment: Some methodological considerations. Journal of applied psychology, 69(3), 372-378.

Meyer, J. P., \& Allen, N. J. (1991). A three-component conceptualization of organizational commitment. Human Resource Management Review, 1(1), 61-89.

Miroshnik, V. (2013). Organizational culture and commitment: Transmission in multinationals. Springer.

Mowday, R. T., Steers, R. M., \& Porter, L. W. (1979). The measurement of organizational commitment. Journal of Vocational Behavior, 14(2), 224-247.

Nella, D., Panagopoulou, E., Galanis, N., Montgomery, A., \& Benos, A. (2015).Consequences of job insecurity on the psychological and physical health of Greek civil servants. BioMed Research International, 3(2), 1-8.

Peene, N. (2009). Insecure times: Job insecurity and its consequences on organizational commitment: Occupational commitment as a moderating variable. Tilburg University Human Resource Studies.

Piccoli, B., De Witte, H., \& Pasini, M. (2011). Job insecurity and organizational consequences: How justice moderates this relationship. Romanian Journal of Applied Psychology, 13(2), 37-49.

Probst, T.M., \& Lawler, J. (2006). Cultural values as moderators of employee reactions to job insecurity: The role of individualism and collectivism. Applied Psychology: An International Review, 55(2), 234-254.

Reisel, W. D., Chia, S. L., Maloles III, C. M., \& Slocum Jr, J. W. (2007). The effects of job insecurity on satisfaction and perceived organizational performance. Journal of Leadership \& Organizational Studies, 14(2), 106-116.

Rhoades, L., Eisenberger, R., \& Armeli, S. (2001). Affective commitment to the organization: The contribution of perceived organizational support. Journal of Applied Psychology, 86(5), 825-836.

Richter, A. (2011). Job insecurity and its consequences. Department of Psychology, Stockholm University.

Seçer, B. (2007). Kariyer sermayesi ve istihdam edilebilirliğin iş güvencesizliği üzerindeki etkisi. Dokuz Eylül Üniversitesi Sosyal Bilimler Enstitüsü, Yayınlanmamış Doktora Tezi, İzmir.

Şıklar, E., \& Tunalı, D. (2015). Çalışanların tükenmişlik düzeylerinin incelenmesi: Eskişehir örneği. Dumlupınar Üniversitesi Sosyal Bilimler Dergisi, 33, 75-84.

Smit, N. W., De Beer, L. T., \& Pienaar, J. (2016). Work stressors, job insecurity, union support, job satisfaction and safety outcomes within the iron ore mining environment. SA Journal of Human Resource Management, 14(1), 1-13.

Taşkaya, S., \& Şahin, B. (2011). Hastane çalışanlarının kişisel özellikleri ile örgütsel adalet algılarının örgüte bağlılık düzeyleri üzerine etkisinin yapısal eşitlik modeli ile değerlendirilmesi. Hacettepe Üniversitesi íktisadi ve İdari Bilimler Fakültesi Dergisi, 29(1), 165-185.

Tilakdharee, N., Ramidial, S., \& Parumasur, S. B. (2010). The relationship between job insecurity and burnout. South African Journal of Economic and Management Sciences, 13(3), 254-271.

Tosun, N., \& Ulusoy, H. (2017). The relationship of organizational commitment, job satisfaction and burnout on physicians and nurses?. Journal of Economics \& Management, 28(2), 90-111.

Uslu, T. (2014). Perceptions of organizational commitment, job satisfaction and turnover intentions in M\&A process: $A$ multivariate positive psychology model. Marmara Üniversitesi Sosyal Bilimler Enstitüsü, Yayınlanmamış Doktora Tezi, İstanbul.

Ünsal-Akbıyık, B. S., Çakmak-Otluoğlu, K. Ö., \& Witte, H. D. (2012). Job insecurity and affective commitment in seasonal versus permanent workers. International Journal of Humanities and Social Science, 2(24), 14-20.

Vandenberghe, C., Bentein, K., \& Stinglhamber, F. (2004). Affective commitment to the organization, supervisor, and work group: Antecedents and outcomes. Journal of Vocational Behavior, 64(1), 47-71.

Elst, T. V., De Witte, H., \& De Cuyper, N. (2014). The Job Insecurity Scale: A psychometric evaluation across five European countries. European Journal of Work and Organizational Psychology, 23(3), 364-380.

Wang, H. J., Lu, C. Q., \& Siu, O. L. (2015). Job insecurity and job performance: The moderating role of organizational justice and the mediating role of work engagement. Journal of Applied Psychology, 100(4), 1-10.

Yener, D. (2014). The effects of burnout on organizational commitment in logistics sector. Journal of Business Research Turk, 6(2), 15-25. 
Yürür, S., \& Ünlü, O. (2011). Duygusal emek, duygusal tükenme ve işten ayrılma niyeti ilişkisi. Endüstri İlişkileri ve İnsan Kaynakları Dergisi, 13(2), 81-104.

Zoghbi-Manrique-de-Lara, P., Ting-Ding, J.-M., \& Guerra-Baez, R. (2017). Indispensable, expendable, or irrelevant? Effects of job insecurity on the employee reactions to perceived outsourcing in the hotel industry. Cornell Hospitality Quarterly, 58(1), 69-80. 
This Page Intentionally Left Blank 